\title{
Correction to: Study of Structural, Electronic and Vibrational Properties of Porous Silicon with Different Porosity
}

\author{
H. Lachenani ${ }^{1,2,3} \cdot$ A. Larabi ${ }^{2} \cdot N$. Gabouze $^{2}$
}

Published online: 4 July 2019

(C) Springer Nature B.V. 2019

\section{Correction to: Silicon}

https://doi.org/10.1007/s12633-019-00137-1

The original version of the article unfortunately contained an error.

The third affiliation of author $\mathrm{H}$. Lachenani was inadvertently left out. The complete affiliations are given below.

Publisher's Note Springer Nature remains neutral with regard to jurisdictional claims in published maps and institutional affiliations.

The online version of the original article can be found at https://oi.org/ 10.1007/s12633-019-00137-1
A. Larabi
amina.larabi8@gmail.com

1 Laboratoire de Physique des Techniques Expérimentales et ses Applications de Médéa LPTEAM, Département Science de la Matière, Faculté des Sciences, Université de Médéa, Médéa, Algeria

2 Centre de Recherche en Technologie des Semi-conducteurs pour l'Energétique (CRTSE), 02 Bd, Frantz Fanon, B.P, 140 Alger, Algeria

3 Faculté des Sciences, Département de physique,Y, Université BLIDA1, B.P 270, Route de Soumaa, Blida, Algeria 